This document was prepared in conjunction with work accomplished under Contract No. DE-AC09-96SR18500 with the U. S. Department of Energy.

\title{
DISCLAIMER
}

This report was prepared as an account of work sponsored by an agency of the United States Government. Neither the United States Government nor any agency thereof, nor any of their employees, nor any of their contractors, subcontractors or their employees, makes any warranty, express or implied, or assumes any legal liability or responsibility for the accuracy, completeness, or any third party's use or the results of such use of any information, apparatus, product, or process disclosed, or represents that its use would not infringe privately owned rights. Reference herein to any specific commercial product, process, or service by trade name, trademark, manufacturer, or otherwise, does not necessarily constitute or imply its endorsement, recommendation, or favoring by the United States Government or any agency thereof or its contractors or subcontractors. The views and opinions of authors expressed herein do not necessarily state or reflect those of the United States Government or any agency thereof. 


\section{Test Plan for Characterization Testing of SO2-depolarized Electrolyzer Cell Designs}

February 15, 2006

J. L. Steimke, 786-5A

\begin{tabular}{ll} 
& \multicolumn{1}{c}{$\begin{array}{c}\text { UNCLASSIFIED } \\
\text { DOES NOT CONTAIN } \\
\text { UNCLASSIFIED CONTROLLED } \\
\text { NUCLEAR INFORMATION }\end{array}$} \\
ADC \& & \\
Reviewing \\
Official:
\end{tabular}

Westinghouse Savannah River Company

Savannah River Site

Aiken, SC 29808

Prepared for the U.S. Department of Energy Under Contract Number DE-AC09-96SR18500

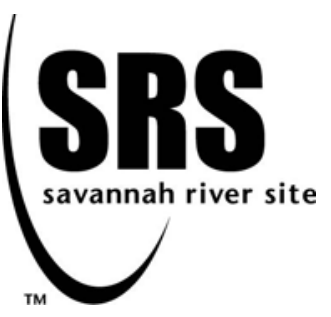




\title{
DISCLAIMER
}

This report was prepared for the United States Department of Energy under Contract No. DE-AC09-96SR18500 and is an account of work performed under that contract. Neither the United States Department of Energy, nor WSRC, nor any of their employees makes any warranty, expressed or implied, or assumes any legal liability or responsibility for accuracy, completeness, or usefulness, of any information, apparatus, or product or process disclosed herein or represents that its use will not infringe privately owned rights. Reference herein to any specific commercial product, process, or service by trade name, trademark, name, manufacturer or otherwise does not necessarily constitute or imply endorsement, recommendation, or favoring of same by Westinghouse Savannah River Company or by the United States Government or any agency thereof. The views and opinions of the authors expressed herein do not necessarily state or reflect those of the United States Government or any agency thereof.

\section{Printed in the United States of America}

\author{
Prepared For \\ U.S. Department of Energy
}




\begin{tabular}{|c|c|c|c|}
\hline $\begin{array}{l}\text { Author: } \\
\text { John L. Steimke }\end{array}$ & Signature: & $\begin{array}{l}\text { Organization: } \\
\text { SRNL, PED }\end{array}$ & Date: \\
\hline $\begin{array}{l}\text { Technical Review (if required): } \\
\text { Zafar Qureshi }\end{array}$ & Signature: & $\begin{array}{l}\text { Organization: } \\
\text { SRNL, PED }\end{array}$ & Date: \\
\hline $\begin{array}{l}\text { Level } 3 \text { Manager (or designee): } \\
\text { R. E. Edwards }\end{array}$ & Signature: & $\begin{array}{l}\text { Organization: } \\
\text { SRNL, ECPT }\end{array}$ & Date: \\
\hline $\begin{array}{l}\text { Customer: } \\
\text { NA }\end{array}$ & Signature: & Organization & Date: \\
\hline $\begin{array}{l}\text { SRNL QAD (CQF): } \\
\text { J. P. Vaughan }\end{array}$ & Signature: & $\begin{array}{l}\text { Organization: } \\
\text { SRNL/QA }\end{array}$ & Date: \\
\hline $\begin{array}{l}\text { Other Approval (if required): } \\
\text { W.A.Summers }\end{array}$ & Signature: & $\begin{array}{l}\text { Organization: } \\
\text { SRNL, ESD }\end{array}$ & Date: \\
\hline Other Approval (if required): & Signature: & Organization: & Date: \\
\hline
\end{tabular}

Distribution:

D. B. Burns, 786-5A

J. P. Vaughan, 773-41A

J. L. Steimke, 786-5A

W.A. Summers, 773-42A 
Task Technical \& QA Plan

Testing of Electrolyzer for Hydrogen Production
WSRC-TR-2006-00069

REV 0

Page 4 of 12

\begin{tabular}{|l|l|l|l|}
\hline $\begin{array}{l}\text { Revision } \\
\text { Number: }\end{array}$ & Page Number: & Date: & Revision: \\
0 & None & $2 / 15 / 2006$ & original \\
\hline & & & \\
\hline
\end{tabular}




\section{INTRODUCTION}

SRNL received funding in FY 2005 to test the Hybrid Sulfur (HyS) Process for generating hydrogen. This technology employs an electrolyzer that uses a sulfur dioxide depolarized anode to greatly reduce the electrical energy requirement. The required current is the same as for conventional electrolysis of water, but the required cell voltage is reduced. The electrolyzer is a key part of HyS technology. Completing the material loop for HyS requires a high temperature decomposition of sulfuric acid to regenerate the sulfur dioxide gas needed for the anode reaction. Oxygen is also produced and could be sold. The decomposition of sulfuric acid is being studied by others in a separately funded task. It is not included in this SRNL task.

In the HyS Process the electrolyzer has two sides, an anode side and a cathode side. Electrical current is passed through the electrolyzer which drives the following two reactions. Hydrogen ions cross from the anolyte to the cathode through a membrane. The presence of sulfur dioxide at the anode greatly reduces the required cell potential to generate hydrogen as compared to electrolyzing water.

Anode $\quad \mathrm{SO}_{2}+2 \mathrm{H}_{2} \mathrm{O}=\mathrm{H}_{2} \mathrm{SO}_{4}+2 \mathrm{H}^{+}+2 \mathrm{e}^{-}$

Cathode $\quad 2 \mathrm{H}^{+}+2 \mathrm{e}^{-}=\mathrm{H}_{2}$

In 2005 SRNL tested two electrolyzers [Steimke and Steeper, 2005], a commercial cell from Proton Energy Systems and an experimental cell from the University of South Carolina. These cells used a membrane electrode assembly (MEA), in which the anode and cathode are in physical contact with the membrane. Testing was conducted at ambient temperature and sulfur dioxide partial pressures of one and two bar. The anolyte was a solution of sulfuric acid with a concentration in the range from $30 \mathrm{wt} \%$ to $70 \mathrm{wt} \%$. Sulfur dioxide gas was dissolved in the anolyte to saturation and hydrogen gas was generated at the cathode. No catholyte was used, however, some water diffused across the membrane. The cell voltage was as much as 0.8 volts less than for conventional water electrolyzer operation (typically 1.5 volts to 2.0 volts). Increasing the partial pressure of sulfur dioxide from one bar to two bar decreased the cell voltage because sulfur dioxide is a reactant. Increasing anolyte flowrate decreased the voltage because this improved mass transfer inside the cell. Increasing cell current increased the voltage because of internal resistance in the cell and electrode polarization.

1.1. Task Definition: This activity requires designing and building a sulfur dioxide depolarized single cell electrolyzer with an area of approximately 40 square centimeters. The cell will use MEA technology. The membrane type and catalyst type have not yet been determined. The electrolyzer cell will be installed in a test loop designed to operate at pressures up to 90 psia and temperatures up to $80^{\circ} \mathrm{C}$. The reason for increasing the partial pressure of sulfur dioxide is to increase the anolyte concentration of sulfur dioxide, a reactant, which should reduce the cell voltage. The reason for increasing temperature is to increase the rate of reaction, which should decrease the cell voltage. The test loop will circulate anolyte, control temperature, have hardware to saturate the anolyte with sulfur dioxide for a range of partial pressures, set a range of pressures on the cathode side of the cell, collect hydrogen that was generated, control temperature and measure flowrates and pressures. The electrolyzer will be tested over a range of temperature, flowrate, partial pressures of sulfur dioxide, sulfuric acid concentration and current density. The goal of the testing will be to minimize cell voltage, consistent with reasonable operating conditions. The results will be documented in a technical report. This work is nonbaseline and R\&D. 
1.2. Customer/Requester: The customer is the Office of the Nuclear Hydrogen Initiative under the Department of Energy.

1.3. Task Responsibilities: The EDL has overall responsibility, will design the electrolyzer cell and test loop, perform the testing and document the results.

1.4 Task Deliverables: One technical report covering the work outlined by this Task Technical Plan (TTP) will be delivered by September 15, 2006. The report will be entitled

“Characterization Testing and Analysis of Single-Cell SO2 Depolarized Electrolyzer". Laboratory notebooks will be available to the customer on request. Data and lab notebooks are handled per the QA Plan Checklist, Section 9.

\subsection{Task Acceptance Criteria \\ none}

\subsection{TASK ACTIVITIES}

\subsection{Complete Conduct of R\&D Process}

1. R\&D Hazards Checklist

2. Environmental Evaluation Checklist

3. Pressure Protection

4. Industrial Hygiene and Chemical Control

5. Fire Protection

6. Management of Safety Basis

7. Job Hazard Analysis

8. Screening Process Hazards Review

\subsection{Design of electrolyzer, specifications}

1. Anolyte is sulfuric acid solution, saturated in $\mathrm{SO}_{2}$. Range of acid concentrations is $30 \mathrm{wt} \%$ to $70 \mathrm{wt} \%$. Anode reaction is $\mathrm{SO}_{2}+2 \mathrm{H}_{2} \mathrm{O}=\mathrm{H}_{2} \mathrm{SO}_{4}+2 \mathrm{H}^{+}+2 \mathrm{e}^{-}$.

2. Cathode reaction is $2 \mathrm{H}^{+}+2 \mathrm{e}^{-}=\mathrm{H}_{2}$. For some tests there will be no catholyte. However, the design will allow for flooding the cathode side of the cell with water. Sufficient pressure on the cathode water may reduce the amount of sulfur dioxide that crosses the membrane. Sulfur dioxide is undesirable on the cathode side because it reacts with hydrogen to produce sulfur. This reaction consumes product hydrogen and tends to plug the cathode with sulfur. Hydrogen gas generated at the cathode is expected to be saturated with water vapor and contain some sulfur dioxide.

3. Temperatures range from $20^{\circ} \mathrm{C}$ to $80^{\circ} \mathrm{C}$.

4. Wetted surfaces of the electrolyzer must withstand these solutions and temperatures.

5. Testing will be conducted at a range of pressures from ambient to 90 psia.

6. Active area is $40 \mathrm{~cm}^{2}+/-10 \mathrm{~cm}^{2}$

7. Range of currents is up to 50 amperes.

8. The range of sulfur dioxide conversions is from $5 \%$ to $50 \%$.

9. Cell design must not be mass transfer limited at typical flowrates.

10. Cell pressure drop across anode side should not exceed 10 psid.

11. Uses membrane electrode assembly (MEA) concept.

12. Cell membrane passes water and hydrogen ions, but resists passing other species. 
13. Design, catalysts and materials for the anode and cathode have not yet been established, but will be determined as the result of a research program conducted by David Hobbs at SRNL.

\subsection{Design of flow loop, including instrumentation}

1. Effective area for the cell is $40 \mathrm{~cm}^{2} \pm 10 \mathrm{~cm}^{2}$.

2. Tentative currents are $5,10,20,30,40$ and $50 \mathrm{~A}$.

3. Maximum voltage is 1.5 volts.

4. Temperature range is $20^{\circ} \mathrm{C}$ to $80^{\circ} \mathrm{C}$. Need way to control temperatures of anolyte. Must insulate cell for higher temperatures.

5. Anolyte is sulfuric acid ranging from $30 \mathrm{wt} \%$ to $70 \mathrm{wt} \%$. For shakedown testing and no electrical current the anolyte will be water.

6. Anolyte contains $\mathrm{SO}_{2}$. Solubility of $\mathrm{SO}_{2}$ depends on temperature and partial pressure of $\mathrm{SO}_{2}$ in the Absorber. Excess $\mathrm{SO}_{2}$ will either be vented outside the building or scrubbed.

7. Prefer upflow for anolyte inside electrolyzer in case $\mathrm{SO}_{2}$ bubbles come out of solution.

8. Need to measure hydrogen generation rate over an hour. Must be able to sample hydrogen for chemical analysis.

9. Range of anolyte flowrate is determined by the range of currents, range of sulfur dioxide conversions and concentration of sulfur dioxide in anolyte.

10. Need chemically resistant anolyte pump.

11. Current and voltage (potential) across cell must be measured.

12. Need capability to set the hydrogen pressure at the cathode 10 psig higher than the anolyte pressure to potentially reduce diffusion of $\mathrm{SO}_{2}$ across the membrane.

13. Initial testing will be for about an hour at each set of conditions. However, there may be a longer run.

14. The anode reaction generates sulfuric acid, so hardware must allow for periodic addition of water to maintain the acid concentration.

15. Need to monitor acid concentration. Sampling followed by density measurement may be adequate.

16. Sulfur dioxide concentration in the anolyte will be measured using wet chemistry.

17. Provide pressure protection as required.

18. All equipment will be installed in a chemical hood that vents outside.

\subsection{Selection and calibration of instruments.}

\subsection{Programming and wiring of Data Acquisition System}

\subsection{Verification of wet chemistry method for measuring sulfur dioxide.}

\subsection{Construction of flow loop including electrolyzer}

\subsection{Shakedown testing}

Using water and no current to the electrolyzer, test pumps, valves, instruments, safety devices and data acquisition system

\subsection{Parametric testing}

1. Two or three cells will be tested

2. Sulfuric acid concentrations, $30 \mathrm{wt} \%, 50 \mathrm{wt} \%, 70 \mathrm{wt} \%$

3. Sulfur dioxide conversions ranging from $5 \%$ to $50 \%$

4. Temperatures of $20^{\circ} \mathrm{C}, 50^{\circ} \mathrm{C}$ and $80^{\circ} \mathrm{C}$.

5. Saturation pressures of $\mathrm{SO}_{2}$ of ambient pressure, 90 psia and intermediate pressure. 
6. Currents ranging from 5 amperes to 50 amperes.

\subsection{A nine hour test at one set of conditions.}

\subsection{Document work in report}

\subsection{Dispose of waste and dismantle any equipment that will not be used in future testing.}

\subsection{REPORTING}

Issue report documenting testing performed in FY 2006.

\subsection{TASK SCHEDULE:}

February 15, $2006 \quad$ Complete Test Plan

September 15, $2006 \quad$ Complete testing and issue report

6. 0. RESEARCH FACILITY PLANNING: Laboratory space is available at the EDL for this task. Testing will be conducted in a large chemical hood.

7.0. PROGRAMMATIC RISK REVIEW: The following depicts the programmatic risks associated with this task and the associated mitigation, where identified.

\section{Programmatic Risk and Mitigation}

\begin{tabular}{|l|l|l|}
\hline $\begin{array}{l}\text { Risk } \\
\text { Factor }\end{array}$ & \multicolumn{1}{|c|}{ Event } & Mitigation \\
\hline Equipment & Failure & Replacement of item \\
\hline Personnel & $\begin{array}{l}\text { Illness } \\
\text { Vacation }\end{array}$ & $\begin{array}{l}\text { Primary and secondary researchers and analysts } \\
\text { identified. }\end{array}$ \\
\hline Facility & $\begin{array}{l}\text { Outage: } \\
\text { Electrical } \\
\text { Ventilation }\end{array}$ & Adjust testing intervals. \\
\hline
\end{tabular}

\subsection{REFERENCES}

J. L. Steimke and T. J. Steeper, “Characterization Testing of $\mathrm{H}_{2} \mathrm{O}-\mathrm{SO}_{2}$ Electrolyzer at Ambient Pressure”, WSRC-TR-2005-00310, August 2005. 


\subsection{QA Plan Checklist}

The following QA Procedures apply for this task (indicate Yes, No or "AR" - as required). Current revision of the procedure will be used. The QA controls are the procedures identified on the checklist. If the procedures on the matrix are changed, applicable procedures will be followed.

\begin{tabular}{|c|c|c|}
\hline Yes & No & Title \\
\hline & & 1-1 ORGANIZATION \\
\hline $\mathrm{X}$ & & 1Q, QAP 1-1, Organization \\
\hline \multirow[t]{2}{*}{$\mathrm{X}$} & & L1, 1.02, SRTC Organization \\
\hline & & \\
\hline \multirow{3}{*}{$\mathrm{X}$} & & 10, OAP 1-2, Stop Work \\
\hline & & \\
\hline & & 2-1 QUALITY ASSURANCE PROGRAM \\
\hline $\mathrm{X}$ & & 1Q, QAP 2-1, Quality Assurance Program \\
\hline \multirow[t]{2}{*}{$\bar{X}$} & & L1, 8.02, SRTC QA Program Clarifications, Attachment 8.2-1 \\
\hline & & 2-2 PERSONNEL TRAINING \& QUALIFICATION \\
\hline $\mathrm{X}$ & & 1Q, QAP 2-2, Personnel Training \& Qualification \\
\hline \multirow[t]{4}{*}{$\mathrm{X}$} & & L1, 1.32, Read \& Sign \\
\hline & & \\
\hline & & \\
\hline & & 2-3 CONTROL OF RESEARCH \& DEVELOPMENT ACTIVITIES \\
\hline $\mathrm{X}$ & & 1Q, QAP 2-3, Control of Research \& Development Activities \\
\hline $\mathrm{X}$ & & L1, 8.02, SRTC QA Program Clarifications, Attachment 8.2-3 \\
\hline $\mathrm{X}$ & & L1, 7.10, Control of Technical Work \\
\hline $\mathrm{X}$ & & L1, 7.16, Laboratory Notebooks and Logbooks \\
\hline \multirow[t]{12}{*}{$\mathrm{X}$} & & E7, 2.31, Engineering Calculations \\
\hline & & \\
\hline & & 2-4 AUDITOR/LEAD AUDITOR QUALIFICATION \& CERTIFICATION \\
\hline & $\mathrm{X}$ & 1Q, QAP 2-4, Auditor/Lead Auditor Qualification \& Certification \\
\hline & & Not anticipated \\
\hline & & $\begin{array}{l}\text { 2-5 QUALIFICATION \& CERTIFICATION OF INDEPENDENT INSPECTION } \\
\text { PERSONNEL }\end{array}$ \\
\hline & $\mathrm{X}$ & 1Q, QAP 2-5, Qualification \& Certification of Independent Inspection Personnel \\
\hline & & Not anticipated \\
\hline & & 2-6 QA MANUAL REVISION \\
\hline & $\mathrm{X}$ & 1Q, QAP 2-6, QA Manual Revisions \\
\hline & & Not anticipated \\
\hline & & $\begin{array}{l}\text { 2-7 QA PROGRAM REQUIREMENTS FOR ANALYTICAL MEASUREMENT } \\
\text { SYSTEMS }\end{array}$ \\
\hline \multirow[t]{6}{*}{$\mathrm{X}$} & & 1Q, QAP 2-7, QA Program Requirements for Analytical Measurement Systems \\
\hline & & \\
\hline & & 3-1 DESIGN CONTROL \\
\hline & $\mathrm{X}$ & 1Q, QAP 3-1, Design Control \\
\hline & $\bar{X}$ & L1, 7.10, Control of Technical Work \\
\hline & & 4-1 PROCUREMENT DOCUMENT CONTROL \\
\hline
\end{tabular}




\begin{tabular}{|c|c|c|}
\hline \multirow{2}{*}{$\begin{array}{l}\text { Yes } \\
\mathrm{X}\end{array}$} & \multirow[t]{2}{*}{ No } & Title \\
\hline & & 1Q, QAP 4-1, Procurement Document Control \\
\hline \multirow[t]{3}{*}{$\mathrm{X}$} & & E7, 3.10, Determination of Quality Requirements for Procured Items \\
\hline & & Not anticipated \\
\hline & & 5-1 INSTRUCTIONS, PROCEDURES \& DRAWINGS \\
\hline $\mathrm{X}$ & & 1Q, QAP 5-1, Instructions, Procedures \& Drawings \\
\hline $\mathrm{X}$ & & E7, 2.30, Drawings \\
\hline \multirow[t]{2}{*}{$\mathrm{X}$} & & L1, 1.01, SRTC Procedure Administration \\
\hline & & \\
\hline \multirow{4}{*}{$\mathrm{X}$} & & 10 OAP 6-1 Document Control \\
\hline & & \\
\hline & & \\
\hline & & 7-2 CONTROL OF PURCHASED ITEMS \& SERVICES \\
\hline $\mathrm{X}$ & & 1Q, QAP 7-2, Control of Purchased Items \& Services \\
\hline $\mathrm{X}$ & & 7B, Procurement Management Manual (for reference) \\
\hline \multirow[t]{7}{*}{$\mathrm{X}$} & & 3E, WSRC Procurement Specification Manual (for reference) \\
\hline & & Not anticipated \\
\hline & & 7-3 COMMERCIAL GRADE ITEM DEDICATION \\
\hline & $\mathrm{X}$ & 1Q, QAP 7-3, Commercial Grade Item Dedication \\
\hline & $\underline{X}$ & E7, 3.46, Replacement Item Evaluation/Commercial Grade Item Dedication \\
\hline & & Not applicable \\
\hline & & 8-1 IDENTIFICATION \& CONTROL OF ITEMS \\
\hline $\mathrm{X}$ & & 1Q, QAP 8-1, Identification \& Control of Items \\
\hline \multirow[t]{24}{*}{$\mathrm{X}$} & & L1, 8.02, SRTC QA Program Clarifications, Attachment 8.8-1 \\
\hline & & Not applicable \\
\hline & & 9-1 CONTROL OF PROCESSES \\
\hline & $\mathrm{X}$ & 1Q, QAP 9-1, Control of Processes \\
\hline & & Not applicable \\
\hline & & 9-2 CONTROL OF NONDESTRUCTIVE EXAMINATION \\
\hline & $\mathrm{X}$ & 1Q, QAP 9-2, Control of NDE \\
\hline & & Not applicable \\
\hline & & 9-3 CONTROL OF WELDING \& OTHER JOINING PROCESSES \\
\hline & $\mathrm{X}$ & 1Q, QAP 9-3, Control of Welding \& Other Joining Processes \\
\hline & & Not applicable \\
\hline & & 9-4 WORK PROCESSES \\
\hline & $\mathrm{X}$ & 1Q, QAP 9-4, Work Processes \\
\hline & $\bar{X}$ & 1Y, 8.20, Work Control Procedure \\
\hline & & Not applicable \\
\hline & & 10-1 INSPECTION \& VERIFICATION \\
\hline & $\mathrm{X}$ & 1Q, QAP 10-1, Inspection \& Verification \\
\hline & $\mathrm{X}$ & L1, 8.10, Inspection \\
\hline & & No inspections \\
\hline & & \\
\hline & & 11-1 TEST CONTROL - (R\&D Test activities are controlled by 1Q, QAP 2-3) \\
\hline & $\mathrm{X}$ & 1Q, QAP 11-1, Test Control \\
\hline & & Not applicable \\
\hline & & 12-1 CONTROL OF MEASURING \& TEST EQUIPMENT \\
\hline $\mathrm{X}$ & & 1Q, QAP 12-1, Control of Measuring \& Test Equipment \\
\hline
\end{tabular}




\begin{tabular}{|c|c|c|}
\hline \multirow[t]{3}{*}{ Yes } & No & Title \\
\hline & & 12-2 CONTROL OF INSTALLED PROCESS INSTRUMENTATION \\
\hline & $\mathrm{X}$ & 1Q, QAP 12-2, Control of Installed Process Instrumentation \\
\hline & & Not applicable \\
\hline & & $\begin{array}{l}\text { 12-3 CONTROL \& CALIBRATION OF RADIATION MONITORING } \\
\text { EQUIPMENT }\end{array}$ \\
\hline & $\mathrm{X}$ & 1Q, QAP 12-3, Control of Radiation Monitoring Equipment \\
\hline & & No radiation \\
\hline & & 13-1 PACKAGING, HANDLING, SHIPPING \& STORAGE \\
\hline $\mathrm{X}$ & & 1Q, QAP 13-1, Packaging, Handling, Shipping \& Storage \\
\hline \multirow[t]{3}{*}{$\bar{X}$} & & L1, 8.02, SRTC QA Program Clarifications, Attachment 8.13-1 \\
\hline & & No shipping \\
\hline & & 14-1 INSPECTION, TEST \& OPERATING STATUS \\
\hline $\mathrm{X}$ & & 1Q, QAP 14-1, Inspection, Test \& Operating Status \\
\hline \multirow[t]{3}{*}{$\mathrm{X}$} & & L1, 8.02, SRTC QA Program Clarifications, Attachment 8.14-1 \\
\hline & & No inspection \\
\hline & & 15-1 CONTROL OF NONCONFORMING ITEMS \\
\hline $\mathrm{X}$ & & 1Q, QAP 15-1, Control of Nonconforming Items \\
\hline \multirow[t]{3}{*}{$\mathrm{X}$} & & L1, 8.02, SRTC QA Program Clarifications, Attachment 8.15-1 \\
\hline & & Not anticipated \\
\hline & & 15-2 CONTROL OF NONCONFORMING ACTIVITIES \\
\hline $\mathrm{X}$ & & 1.01, MP 5.35, Corrective Action Program \\
\hline \multirow[t]{3}{*}{$\mathrm{X}$} & & 1B MRP 4.23 Site Tracking Analysis and Reporting \\
\hline & & Not anticipated \\
\hline & & 16-3 CORRECTIVE ACTION SYSTEM \\
\hline $\mathrm{X}$ & & 1Q, QAP 16-3, Corrective Action Program \\
\hline $\mathrm{X}$ & & 1.01, MP 5.35, Corrective Action Program \\
\hline \multirow[t]{3}{*}{$\bar{X}$} & & 1B MRP 4.23 Site Tracking Analysis and Reporting \\
\hline & & Not anticipated \\
\hline & & 17-1 QA RECORDS MANAGEMENT \\
\hline $\mathrm{X}$ & & 1Q, QAP 17-1, QA Records Management \\
\hline \multirow[t]{19}{*}{$\mathrm{X}$} & & L1, 8.02, SRTC QA Program Clarifications, Attachment 8.17-1 \\
\hline & & \\
\hline & & 18-2 QUALITY ASSURANCE SURVEILLANCES \\
\hline & $\mathrm{X}$ & 1Q, QAP 18-2, Quality Assurance Surveillance \\
\hline & & \\
\hline & & 18-3 QUALITY ASSURANCE EXTERNAL AUDITS \\
\hline & $\mathrm{X}$ & 1Q, QAP 18-3, Quality Assurance External Audits \\
\hline & & Not anticipated \\
\hline & & 18-4 MANAGEMENT ASSESSMENTS \\
\hline & $\mathrm{X}$ & 1Q, QAP 18-4, Management Assessments \\
\hline & $\mathrm{X}$ & 12Q, Assessment Manual \\
\hline & & Not anticipated \\
\hline & & \\
\hline & & 18-6 QUALITY ASSURANCE INTERNAL AUDITS \\
\hline & $\mathrm{X}$ & 1Q, QAP 18-6, Quality Assurance Internal Audits \\
\hline & & Not anticipated \\
\hline & & 18-7 QUALITY ASSURANCE SUPPLIER SURVEILLANCE \\
\hline & $\mathrm{X}$ & 1Q, QAP 18-7 Quality Assurance Supplier Surveillance \\
\hline & & Not applicable \\
\hline
\end{tabular}




\begin{tabular}{|l|l|l|}
\hline Yes & No & Title \\
\hline & & 19-2 QUALITY IMPROVEMENT \\
\hline $\mathrm{X}$ & & 1Q, QAP 19-2, Quality Improvement \\
\hline $\mathrm{X}$ & & L1, 8.02, SRTC QA Program Clarifications, Attachment 8.19-2 \\
\hline & & \\
\hline & & 20-1 SOFTWARE QUALITY ASSURANCE \\
\hline & $\mathrm{X}$ & 1Q, QAP 20-1, Software Quality Assurance \\
\hline & $\mathrm{X}$ & L1, 8.20, Software Management \& Quality Assurance \\
\hline & & No software \\
\hline & & 21-1 ENVIRONMENTAL QUALITY ASSURANCE \\
\hline & $\mathrm{X}$ & 1Q, QAP 21-1, QA Requirements for the Collection \& Evaluation of Environ. Data \\
\hline & & No environmental data \\
\hline & & $\begin{array}{l}\text { In addition to procedures noted above, if RW-0333P requirements are invoked, the } \\
\text { following procedures apply. These procedures may also apply at the discretion of the } \\
\text { Task Leader to non-RW-0333P tasks. }\end{array}$ \\
\hline & & \\
\hline & $\mathrm{X}$ & L1, 8.21, Supplemental QA Requirements for RW-0333P \\
\hline $\mathrm{X}$ & & L1, 7.15, Obtaining Analytical Support \\
\hline & $\mathrm{X}$ & L7.7, 1.16, Radioactive Sample Receiving, Labeling, \& Tracking \\
\hline $\mathrm{X}$ & & L1, 7.16, Laboratory Notebooks and Logbooks \\
\hline
\end{tabular}

\section{Identify any exceptions or additions to the procedures listed in the QA Matrix.}

WSRC-IM-2002-00011, “Technical Report Design Check Guidelines,” will be used to help ensure the quality and consistency of the technical review process for technical reports produced by SRNL.

\section{N/A, no software will be developed for this task}

\section{Document Approval}

\begin{tabular}{|l|l|lr|rr|}
\hline \multicolumn{1}{|c|}{ Document } & \multicolumn{2}{|c|}{ Management } & \multicolumn{2}{c|}{ Customer } & \multicolumn{2}{c|}{ CQF } \\
\hline & Yes No & Yes & No & Yes r & No \\
\hline & & & & & \\
\hline Technical \& QA Plan & $X$ & & $X$ & X \\
\hline Final Report & $X$ & $X$ & & & $X$ \\
\hline
\end{tabular}

\section{Anticipated Records:}

The following records are anticipated from this task.

\begin{tabular}{|l|l|l|}
\hline \multicolumn{1}{|c|}{ Yes } & \multicolumn{1}{|c|}{ No } & \multicolumn{1}{c|}{ Description } \\
\hline & & \\
\hline$X$ & & Task Technical \& QA Plan \\
\hline$X$ & & Technical Notebooks \\
\hline$X$ & & Final report \\
\hline & & \\
\hline
\end{tabular}

